\title{
Soil Chemistry to Support Old Map Analysis of the Built-up Area of an Abandoned Settlement. Case Study from the Romanian Banat
}

\author{
Markéta Šantrůčkováa ${ }^{*}$, Jan Horák ${ }^{\mathrm{b}}$, Václav Fanta ${ }^{\mathrm{b}}$ \\ ${ }^{a}$ Silva Tarouca Research Institute for Landscape and Ornamental Gardening, Květnové náměstí 391, 25243 Průhonice, Czech Republic \\ ${ }^{b}$ Faculty of Environmental Sciences, Czech University of Life Sciences, Kamýcká 129, 16521 Prague 6-Suchdol, Czech Republic
}

\section{A RTICLE INFO}

\section{Article history:}

Received: $23^{\text {rd }}$ May 2019

Accepted: $8^{\text {th }}$ June 2020

DOI: http://dx.doi.org/10.24916/iansa.2020.1.8

\section{Key words.}

multi-element analysis

XRF

GIS interpolation

settlement development

old maps

abandoned village

\begin{abstract}
$A B S T R A C T$
This paper focuses on the combination of geochemical methods and old map analysis to study landscape and settlement development. It is well known that historical land use of abandoned rural settlements affects soil chemistry and vegetation composition. We wanted to find out whether it is possible to distinguish various historical land uses when we know the current chemical composition of the soil; in particular, whether it is possible to recognize the presence of an abandoned village. Geochemical measurement was combined with old maps and grey literature analysis. The model area in the Romanian Banat Mountains is well documented by preserved old maps and is even documented by a land allocation plan from the beginning of the $19^{\text {th }}$ century colonization. This unique document was compared with other old maps, and the spatial development of the rural settlement in the Romanian Banat was analysed. The geochemical methods revealed interpretable patterns, but in situations of little-known historical context (we do not know which households were really inhabited); the use of other supporting methods (archaeological topography, geophysics) is recommended.
\end{abstract}

\section{Introduction}

The landscape is still changing, and many authors (Antrop, 2005; Dossche et al., 2016; Wulf et al., 2016) have stressed that landscape changes in Europe have accelerated from the end of the $18^{\text {th }}$ century. Landscape studies focused on land use and land cover changes have a tradition in all parts of Europe (Jepsen et al., 2015; Kuemmerle et al., 2016), as well as in selected regions and land categories (Forejt et al., 2017; Skaloš et al., 2011; Šantrůčková et al., 2015; Wulf et al., 2016). The Romanian mountains seem to be a stable area in macroscopic analyses on a European scale (Jepsen et al., 2015; Kuemmerle et al., 2016), but important settlement and land use/land cover changes have occurred there since the nineteenth century (Cepraga, 2014; Romportl et al., 2014; Šantrůčková, Fanta, 2014; Kováŕ et al., 2019). These changes were connected with the resettlement of Romanian mountains at the beginning of the nineteenth century, which caused an intensification of agriculture and mining activities (Šantrůčková, Klvač, 2014). On the other hand, the Romanian mountains are still one of the hotspots of the traditional cultural landscape in Europe due to their isolation, geographical conditions and ethnographical diversity (Solymosi, 2011). The study of the first settlement activities and landscape changes at the beginning of the nineteenth century requires the combining of different sources and methods. Our paper proposes the combination of geochemical methods used by environmental archaeology with the study of cartographical sources and old grey literature.

The relationship between human settlement activities and the soil part of the biosphere has been intensively studied over the decades, which has introduced a wide spectrum of topics: the influence of the soils on the placement of human activities in the landscape; the interaction between human activities and the soils; the role of soils as one of the basic archives of archaeological evidence; and the role of human activities as a pedogenic factor (Bork et al., 1998; Walkington, 2010; Fanta et al., 2018). Nevertheless, there are also incentives for a more comprehensive research, as many projects are still focused on either an historical or a 
natural perspective, without the two perspectives being brought together. For example, Rainer Schreg (2014) writes about the need to use an ecological approach in landscape archaeology, where the traditional approaches typically aim only at the reconstruction of the environment. We see the topic from another side: a lack of archaeological and paleoenvironmental methods being combined with purely historical topics - and with medieval and modern periods (at least in the central European area, where environmental archaeology chiefly researches prehistoric times).

Soils at archaeological sites are studied in many ways: macroscopically (Kristiansen, 2001); micromorphologically; and geochemically. Some studies have focused on using phosphorus (Holliday, Gartner, 2007), and other studies have focused on using multi-element analyses. These analyses have mostly focused only on the differentiation of basic archaeological features (houses, fields, hearths, etc.), on the verification of human activities, and on analysing the spatial distribution of these activities (Davidson et al., 2007; Nielsen, Kristiansen, 2014; Roos, Nolan, 2012). The topic of the spatial extent of particular activities (e.g. manuring) or land-use types (arable field, pastures, meadows, gardens) has also been studied (Entwistle et al., 1998; Entwistle et al., 2000; Salisbury, 2013). A study coming from Romania (Pîrnău et al., 2020) has also been published.
It is well known that historical land use of abandoned rural settlements affects soil chemistry and vegetation composition, even over the long term (Hejcman et al., 2013; Hejcman et al., 2013; Součková et al., 2013). Therefore, our question was whether it is possible to distinguish various historical land uses if we know the current chemical composition of the soil; in particular, whether it is possible to recognize the presence of an abandoned village. The present study focused on the settlement development of Eibenthal village in the Romanian Banat, which was colonized in the 1820 s by Czech inhabitants. This village was selected to be a model area because the village history is well documented by preserved old maps (even by a land allocation plan from the beginning of this colonization). Moreover, the story of recolonization, place translations and shifts are typical for many settlements in such history (Hill, 2013; Klápště, 2012).

Our aims were the following: 1) to determine if the Eibenthal settlement was realized to the full extent as recorded on old maps and 2) to determine how this question can be answered using spatial analysis of geochemical patterns. To sum up, we want to examine whether simple geochemical analysis can be helpful for the historical geographical research on abandoned settlements and what are the limitations of this approach.

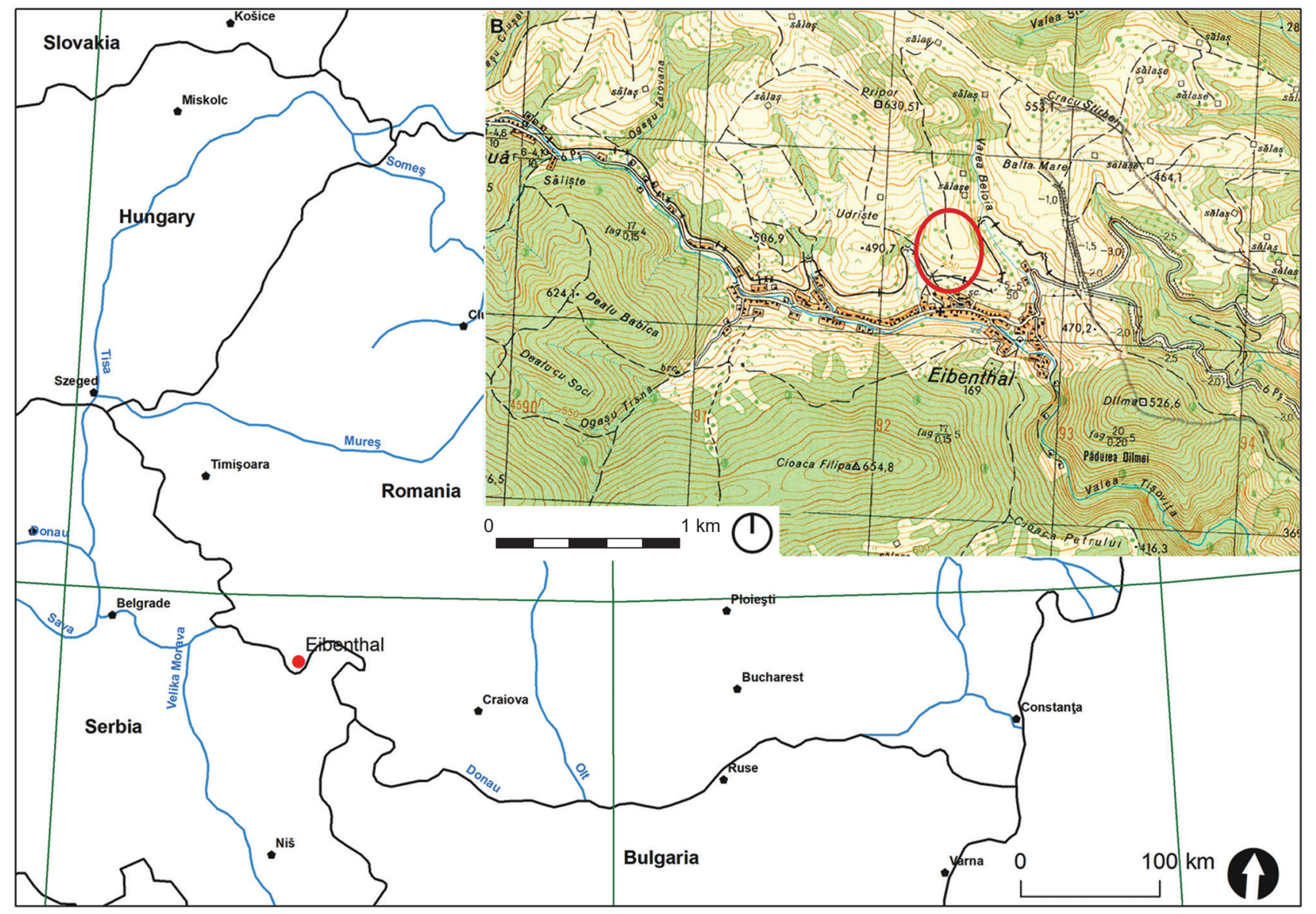

Figure 1. Location of the study area and Eibenthal village. Map sources: ESRI, Word (2017), Romanian topographic map 1:25 000 (probably 1970s). 


\section{Materials and methods}

\subsection{Description of study area and history of the Eibenthal village}

Eibenthal village is located in southwestern Romania (Mehedinti County), in the neighbourhood of the Danube River, which creates a natural border between Romania and Serbia (Figure 1). The village lies in mountainous terrain on the southern edge of the Carpathian Arch, in the Banat Mountains. The village lies in a deforested area within huge forests. The slopes around the village are covered by mosaics of fields, meadows and pastures that are now endangered by abandonment and spontaneous reforestation (Romportl et al., 2014).

This area was recolonized rather late. Eibenthal is one of six current Czech villages in the Romanian Banat: Eibenthal (Eibental), Gârnic (Gerník), Bigăr (Bígr), Ravensca (Rovensko), Sfanta Elena (Svatá Helena), and Şumiţa (Šumice). The area was recolonized as part of the Habsburg monarchy military border after the defeat of the Turks and their displacement behind the Danube River in the late eighteenth century. The arrival of Czechs to the Banat region dates back to the 1820s. The Czech settlers recolonized mainly higher woody areas. The aims of this recolonization were to deforest the area in order to cut wood and extend agricultural land, to establish a new settlement after the Turkish conquest and to strengthen the protection of borders (Iordache, 2007). The settlement of the Czech villages was predominantly organized by military border officers. Before the settlers arrived, military officials measured off parcels of land for future houses and fields that were to be allocated to the immigrants (Pavlásek, 2010). Each family was allocated approximately 7 ha of land (5.2 ha of fields and 1.7 ha of meadows). There were common pastures. Land was distributed to each family so that no one received land that was more fertile or more easily accessible than the other families; as a result, each family's holdings were spread throughout the cadastral territories of the planned villages. Military offices prepared provisional homes (sunken huts or wooden cottages) for the settlers (Pavlásek, 2010; Štěpánek, 2005). However, the land that they were allocated was mostly old growth forest. The colonists had to first cut the forest and pull out the stumps to farm their allocated fields and meadows. The provisional lodgings that they received were not sufficient, and diseases began to spread. In some places, once deforestation was started, there were water shortages. Due to all of these hardships, settlements were established slowly; some had to be relocated, and others were even abandoned (Gecse, 2013; Urban, 2005). Therefore, in the first two or three decades of their existence,

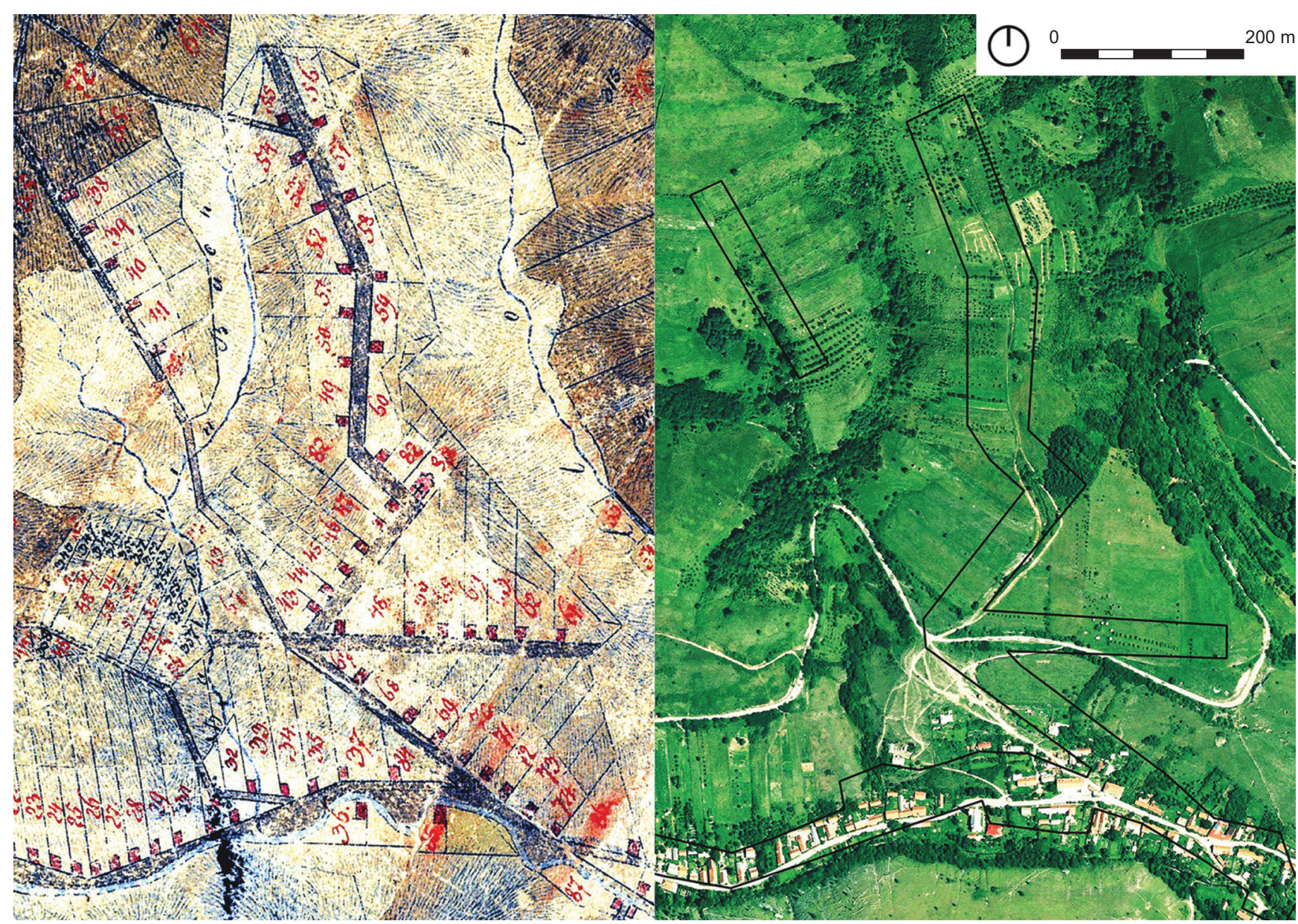

Figure 2. Detail of the study area on the present orthophotomap (2007) and old allocation plan (1826). 
these new settlements were very unstable. Some colonists tried to return to the Czech lands; others wanted to relocate to already existing villages in flatter and more fertile areas of Banat. Military officers, however, opposed such actions because they needed people to settle less fertile areas at higher elevations (Jech et al., 1992; Šantrůčková, Klvač, 2014). The settlement of Czech villages in the Banat region stabilized in the middle of the nineteenth century.

The popular tradition says that Eibenthal village was originally founded far away on the northern slope and plateau (Figure 2), but after several years it was moved to the present and more suitable position near the stream (Urban, 2005). The population in Eibenthal grew from 356 inhabitants in 1830 (Czoernig, 1857) and peaked before WWII (960 inhabitants in 1930) (Urban, 2005). Two waves of decolonization occurred after WWII: the first occurred just after WWII, and the second started in the 1990s. In the years after WWII (1946-1949), Czechoslovakia invited Czechs from abroad to colonize Czech borderlands from which the Germans were expelled (Heroldová, 1986; Vaculík, 1993). More than one-third of the inhabitants left Eibenthal (Secká, 1995). The second decolonization wave started after the fall of the Communist regimes in Czechoslovakia and Romania in 1989 and still continues. The migration is economically motivated, and only approximately 200 inhabitants live in Eibenthal now (Šantrůčková, Klvač, 2014).

\subsection{Old maps}

Four old maps are available for Eibenthal village and its environment; one map is at a large scale, and three maps are at a medium scale (old military maps of the Habsburg Empire).

The large-scale map is titled Grund Eintheilungs Plan von dem Orte Eibenthal (Plan of land allocation in the place named Eibenthal), and according to the text in the map sheet, the map was made in 1826 by sergeant Georg Gimbosch and was confirmed by supply officer Pavich (Figure 3). This map is kept by the Regional cadastral office for the Mehedinţi Region in Orşova, Romania (Oficiile de Cadastru şi Publicitate Imobiliară, Orşova). It has a graphical scale (ca. 1:2880). The map consists of four parts. According to the legend, the map contains fields, meadows, pastures, house plots, and vegetable gardens that are numbered. Furthermore, paths, water streams, and forests are shown on the map, and relief is demonstrated by hatching. On the map, the village ( 88 houses) is located not only around the water

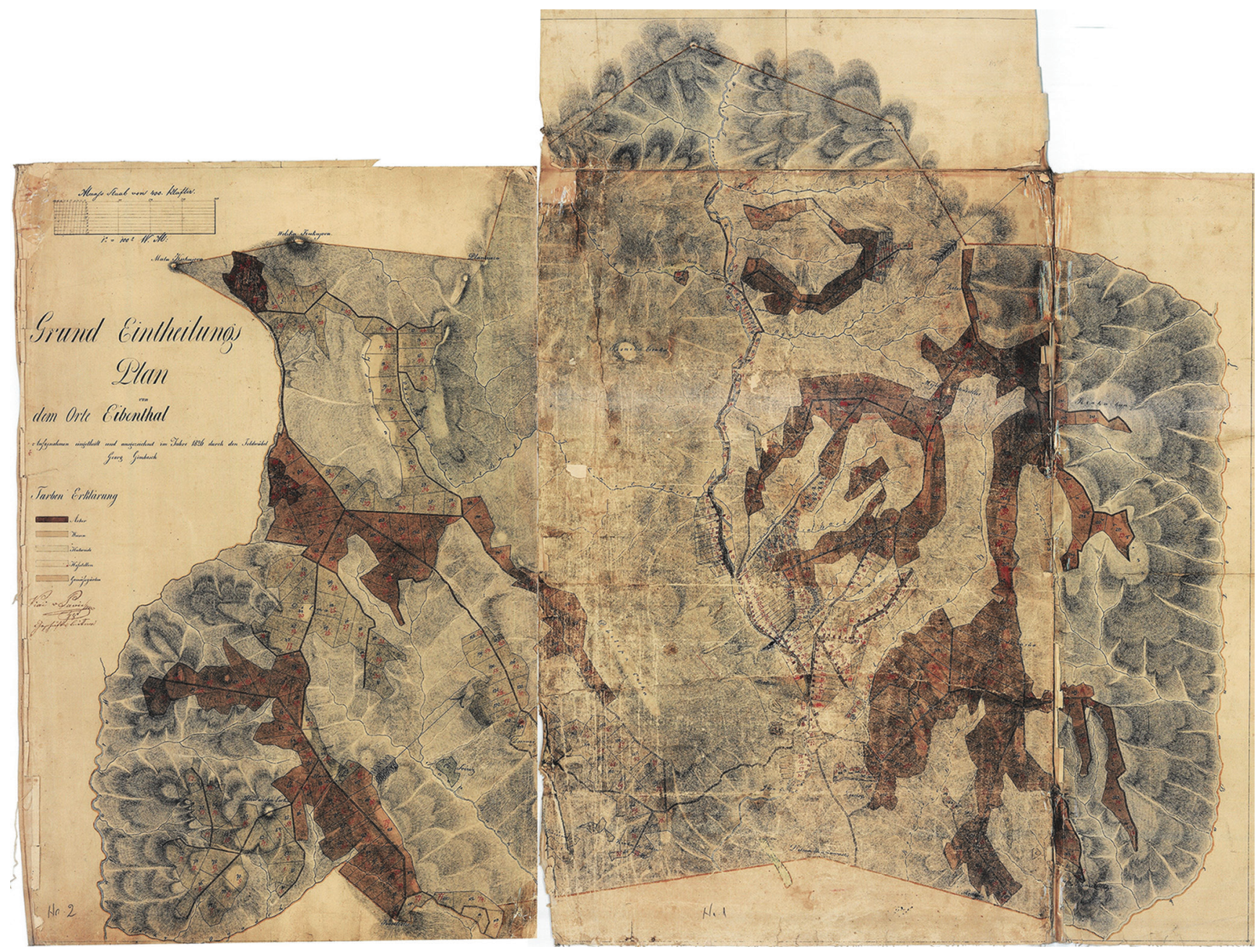

Figure 3. Plan of land allocation in the place named Eibenthal made in 1826. 


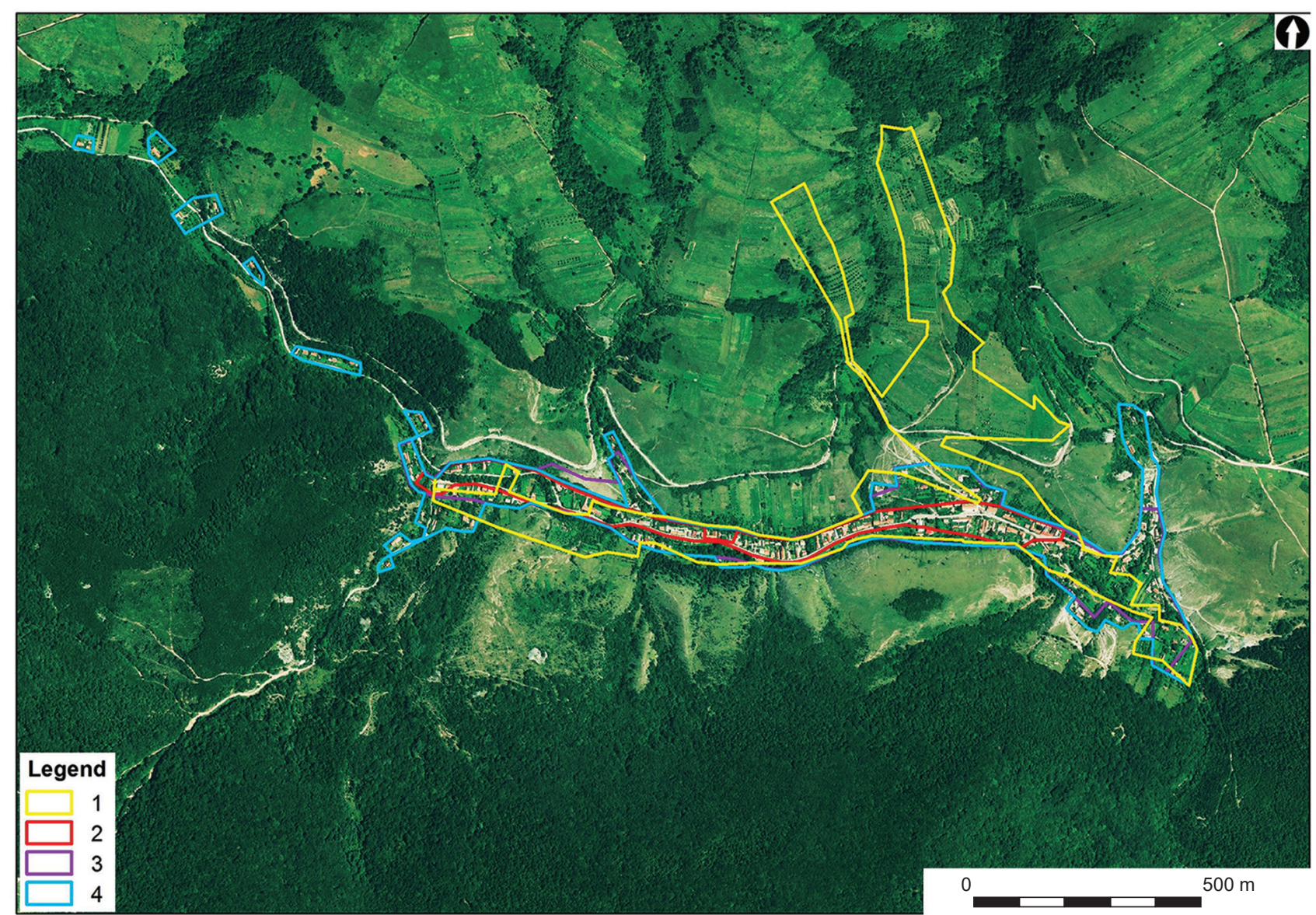

Figure 4. Analysis of the built-up area of Eibenthal village on the old and present maps. Legend: 1 - Map from 1826; 2 - Second Military Map from the mid-nineteenth century; 3 - Third Military Map from the 1870s-1880s; 4 - Contemporary orthophotomap from 2007.

stream but also on the northern slope, including the church/ chapel (Figure 2). In contrast, the present village is located only around the stream (and is longer), and the church is in the bottom of the valley. There are fields and grasslands on the northern slope, and there are no houses or church. It is highly probable that the map shows the planned distribution of the houses and agriculture land as prepared by the military officer for the new arriving colonists.

The old military maps (Biszak et al., 2014; http:// mapire.eu/en/) show the spatial development of the village environment in the eighteenth and nineteenth centuries. The First Military Mapping of Temeschwarer Banat (1769-1772) shows the situation before Eibenthal's founding, and there were only forests. The Second Military Mapping of Hungary (1819-1869) depicts Eibenthal only in the Tisoviţa valley; the agricultural land is on the northern slope, and a church is not present. Eibenthal, including the church, is located in Tisoviţa valley in the Third Military Mapping of Hungary (1869-1887), and there are more houses depicted than on the Second Military Maps. The coal railway crossed the northern slope along the contour line.

For the further analysis, we used the map from 1826, and Second and Third Military Maps. We bought scanned sheets of these maps. The maps were georeferenced on the base of the present ortophotomap (2007) by GIS (ArcGIS 10.1).
Then, the boundaries of settled areas were digitalized on each of the old maps and on the present orthophotomap and it was visualized (Figure 4).

\subsection{Research design}

The area was sampled according to the old maps to verify the location of the previous settlement. A former railway (now an unpaved road) borders the sample area from the south, and the church and some houses around it (as depicted on the allocation plan) are in the centre of the sampled area (Figures 1 and 2). The area is now used as agricultural land (mainly fields, pastures and orchards).

The data were obtained by a direct field profile measurement using a portable ED-XRF (PXRF) analyser Delta Professional manufactured by Olympus InnovX in the Soil Geochem measurement mode for applications of XRF spectrometry, see Canti and Huisman (2015). Every measurement was performed for an interval of 1 minute with $30 \mathrm{~s}$ of a $10 \mathrm{kV}$ beam and $30 \mathrm{~s}$ of a $40 \mathrm{kV}$ beam. The PXRF model used yields data in the form of weight ppm. The quality of the device measurements was successfully tested by BAS Rudice Ltd. (further information are available on www.bas.cz) on 55 reference materials (e.g., SRM 2709a, 2710a, 2711a, OREAS 161, 164, 166, RTC 405, 408). All the field measurements with GPS coordinates are listed in the Dataset S1 (see Supplementary Online Material). 
Table 1. Basic statistical description of chosen elements. Length stands for the total number of samples, count for successfully measured samples and NAs for unsuccessfully measured samples leading to blank cells in table of measurements. Sigma stands for median of 3-sigma values of the elements. Intervals depict how many 3-sigma intervals cover the range of element content. LE (the last variable) stands for light elements (from $\mathrm{H}$ to Na) which are measured in total together due to XRF method limitations. Elemental content in $\mathrm{mg} / \mathrm{kg}$.

\begin{tabular}{|c|c|c|c|c|c|c|c|c|c|c|c|c|c|c|}
\hline & Si & $\mathbf{P}$ & $\mathbf{S}$ & $\mathbf{K}$ & $\mathrm{Ca}$ & Mn & $\mathbf{F e}$ & Zn & $\mathbf{R b}$ & $\mathrm{Sr}$ & $\mathbf{Z r}$ & $\mathbf{P b}$ & Th & LE \\
\hline length & 154 & 154 & 154 & 154 & 154 & 154 & 154 & 154 & 154 & 154 & 154 & 154 & 154 & 154 \\
\hline count & 154 & 154 & 154 & 154 & 154 & 154 & 154 & 154 & 154 & 154 & 154 & 154 & 154 & 154 \\
\hline NAs & 0 & 0 & 0 & 0 & 0 & 0 & 0 & 0 & 0 & 0 & 0 & 0 & 0 & 0 \\
\hline $\max$ & 230600 & 17381 & 9958 & 61800 & 99200 & 2656 & 62075 & 199 & 88 & 398 & 355 & 39 & 48 & 953100 \\
\hline mean & 82740 & 3058 & 3298 & 9941 & 25649 & 913 & 11500 & 92 & 28 & 128 & 96 & 16 & 23 & 842391 \\
\hline sdev & 46359 & 1860 & 1386 & 7427 & 15693 & 542 & 11051 & 30 & 16 & 63 & 56 & 6 & 10 & 58293 \\
\hline median & 78050 & 2794 & 3128 & 8046 & 23064 & 798 & 8146 & 92 & 23 & 117 & 87 & 16 & 23 & 853300 \\
\hline MAD & 46035 & 1408 & 1449 & 4798 & 13592 & 465 & 9044 & 31 & 15 & 56 & 47 & 6 & 10 & 54782 \\
\hline $\min$ & 2201 & 130 & 372 & 2188 & 4231 & 184 & 175 & 23 & 4 & 33 & 12 & 2 & 4 & 633000 \\
\hline sigma. med & 700 & 109.5 & 65.5 & 86 & 170 & 33 & 87.5 & 5 & 1 & 2 & 2 & 2 & 3 & 1400 \\
\hline intervals & 165 & 80 & 75 & 348 & 281 & 39 & 355 & 19 & 43 & 93 & 87 & 11 & 9 & 116 \\
\hline
\end{tabular}

\subsection{Statistical analyses}

Our dataset was comprised of many elements, from which we have chosen just some for the further analyses and interpretation (mainly due to insufficient number of successful measurements and invalid data due to a high proportion of sigma3 intervals to the element content). Our analyses used the following elements: $\mathrm{Si}, \mathrm{P}, \mathrm{S}, \mathrm{K}, \mathrm{Ca}, \mathrm{Mn}, \mathrm{Fe}, \mathrm{Zn}, \mathrm{Rb}, \mathrm{Sr}, \mathrm{Zr}$, $\mathrm{Pb}$, Th, and LE (light elements $-\mathrm{H}$ to $\mathrm{Na}$ concentrations were grouped together due to the principles of the PXRF method used). The basic matrix therefore consisted of 14 variables and 140 cases. For basic statistical information see Table 1 .

In none of the analyses made we work with the original concentration values. The geochemical data can be generally characterized as (usually) of non-normal distribution (Limpert et al., 2001; Reimann, Filzmoser, 2000) and as compositional data (Reimann et al., 2012; Reimann et al., 2008). According to Reimann et al. (2008), we therefore decided to use clr-transformed data. The abbreviation "clr" stands for centered log-ratio: the data were divided by the geometric mean of the data points, and then, the values were $\log _{10}$ transformed. This process helps to avoid problems with compositional data, where the variable cannot reach any value, but this process is limited by the values of other variables (Reimann et al., 2008). This process enables us to use additional information in the data matrix. We used principle component analysis (PCA) as a basic processing method not only to facilitate the interpretation but also to help distinguish between the possibly different inputs of elements into the soil environment.

Using PCA, we should emphasize some aspects of this process. There are many archaeological-geochemical studies. Many of them work with multi-elemental data, but they do not use them as a multi-variate data set - they just evaluate the elemental content separately for each element (e.g. Entwistle et al., 1998; 2000; Wilson et al., 2005; 2008; 2009; Šmejda et al., 2017; 2018). There have also been research and studies presenting and evaluating the data in a multivariate way using PCA (or other methods like cluster analysis - see, e.g. Salisbury, 2013; 2016). But by using PCA we do not focus on reducing the number of variables (as this is the usual aim with a following choice of obtained components for further analysis and interpretation). As our previous research showed, in some cases, the non-significant components (from the viewpoint of eigenvalue or explained variability) can also bear an anthropogenic signal from the past. Therefore, we use PCA in a more exploratory way of working. This comes from the reality of the content of elements in soils actually coming from various different inputs (e.g. the usual anthropogenic indicators such as $\mathrm{P}, \mathrm{Zn}$, Sr can also come from the geological background). Such an approach has helped us to distinguish the different inputs of elements (in a study of Spindelbach this was mainly the case for P - Horák and Klír, 2017; in a study of Lovětín it helped to distinguish different inputs, e.g. for $\mathrm{Sr}-$ Horák et al., 2018). Regarding the input data for PCA, we used the entire matrix of clr-transformed elemental content as well as elevation. We used an R environment to perform the analyses and interpolations (IDW method). We interpolated element content and principal component (PC) scores.

\section{Results}

The location of Eibenthal village on the oldest map from 1826 differs from the location on the old military and present maps. The map from 1826 presents the Eibenthal area in the Tisoviţa valley, similarly to the Third Military Map, and on the northern slope along two small creeks. The narrowest village area is presented on the Second Military map from the mid nineteenth century, where there is mainly one row of houses along the single main street and Tisoviţa stream. Eibenthal village on the Third Military Map (1870s-1880s) is also located only in Tisoviţa valley alongside the street and stream, but the area is larger than on the previous map, and 


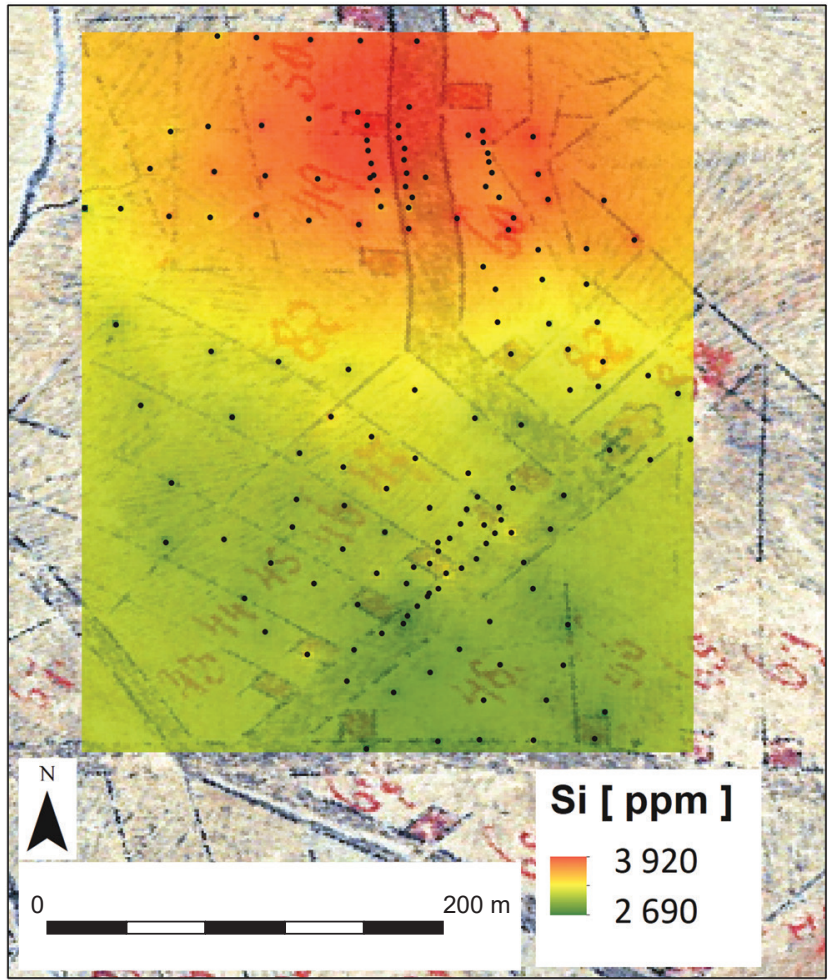

Figure 5. Interpolated content of Si (in ppm) in the sampled area.

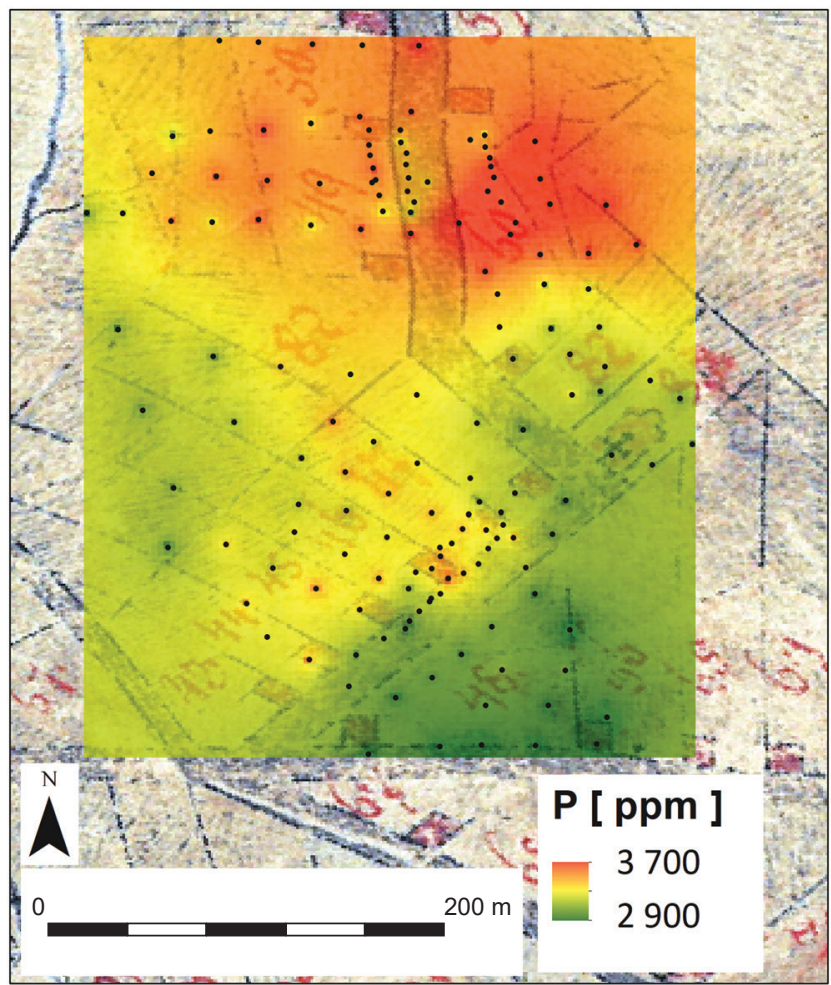

Figure 7. Interpolated content of $\mathrm{P}$ (in ppm) in the sampled area.

the houses on the eastern side are in two rows. The present village area (2007) is based on its state from the end of the nineteenth century, but the area is a little larger because of scattered houses along the road to coal mines in Baia Nouă and along the road to the Danube River (Figure 4).

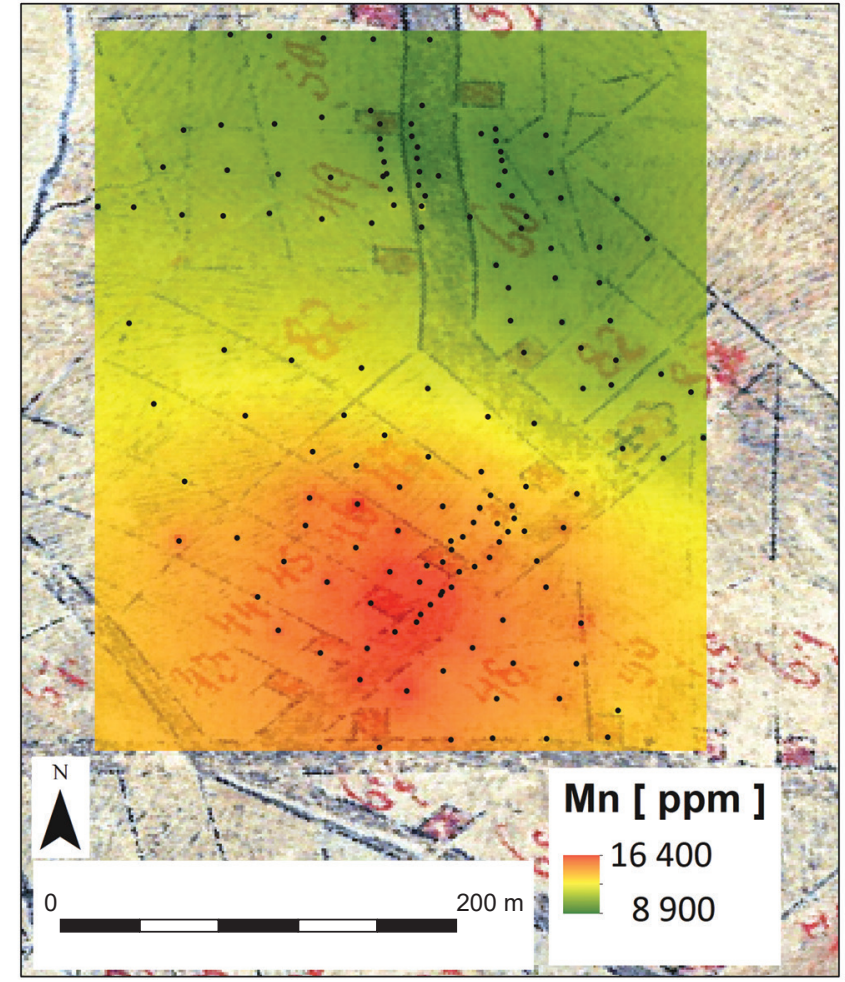

Figure 6. Interpolated content of $\mathrm{Mn}$ (in ppm) in the sampled area.

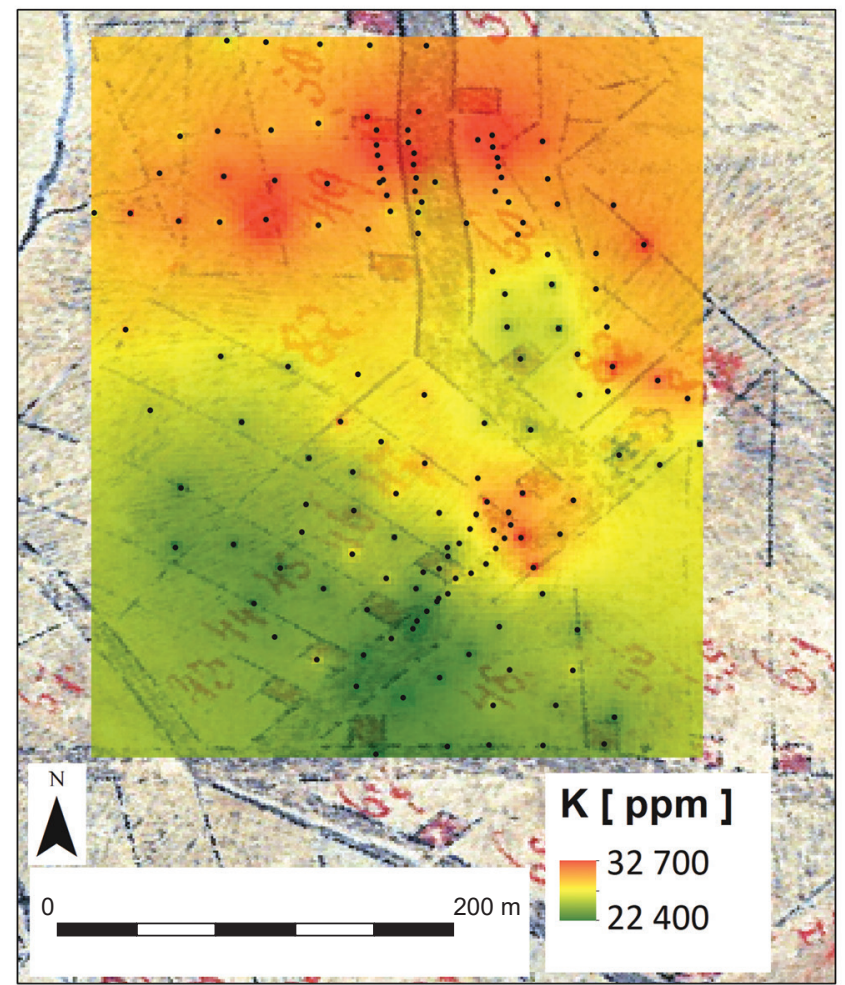

Figure 8. Interpolated content of K (in ppm) in the sampled area.

Elemental content in some cases reached presumed values and relations according to other studies focused on using PXRF in archaeological/paleo-landscape studies (Horák and Klír, 2017; Horák et al., 2018; Šmejda et al., 2017; 2018). However, some of the results were in some aspects different 


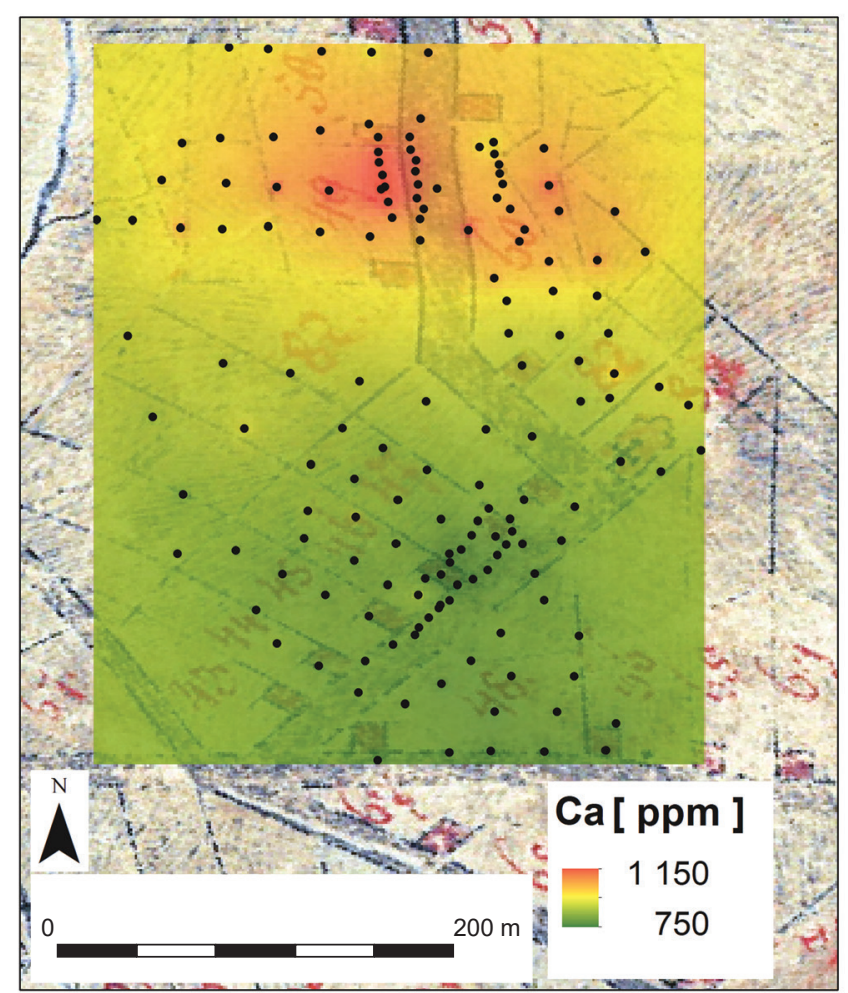

Figure 9. Interpolated content of $\mathrm{Ca}$ (in ppm) in the sampled area.

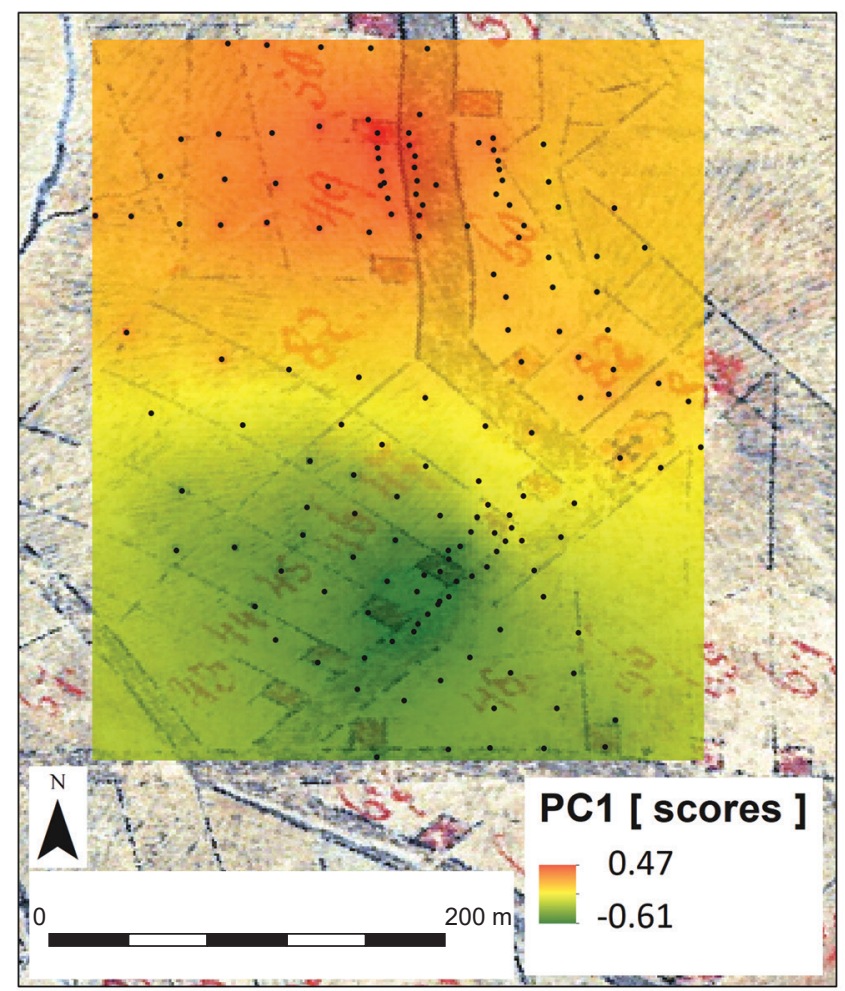

Figure 11. Interpolated scores of $\mathrm{PC} 1$ in the sampled area.

from expectation based on those studies. As an example of this we could state $\mathrm{Pb}$ (a little lower content), and $\mathrm{P}$ or S (of higher content).

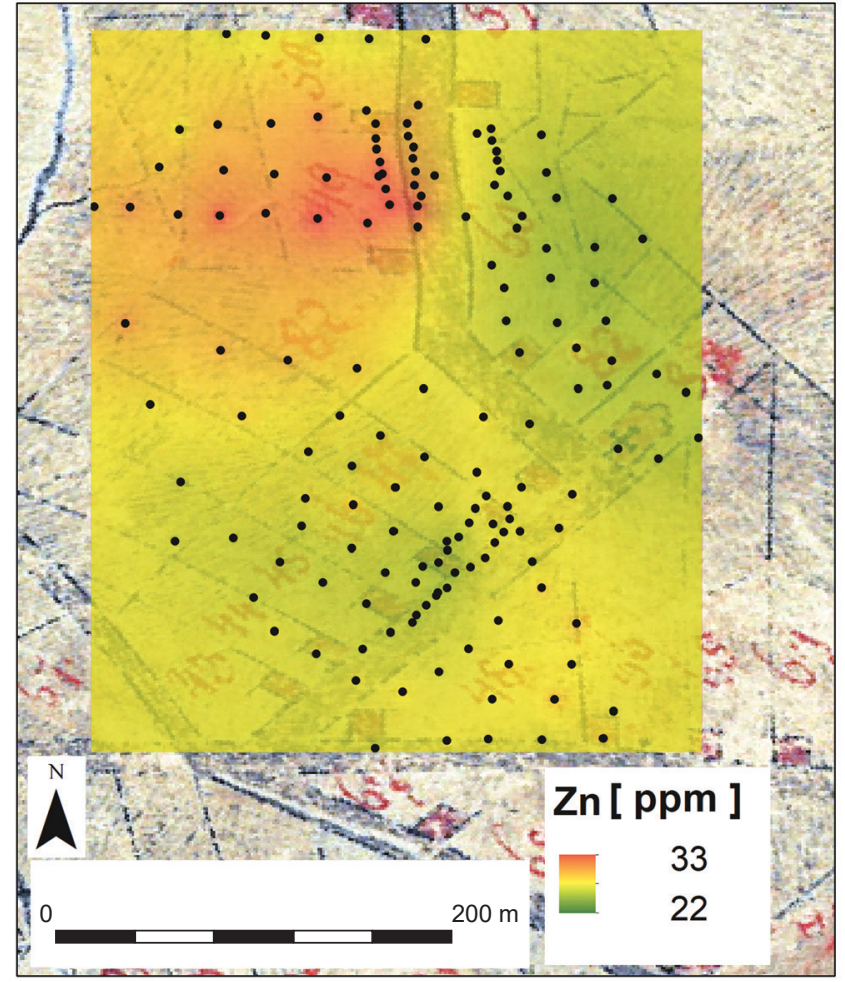

Figure 10. Interpolated content of $\mathrm{Zn}$ (in ppm) in the sampled area.

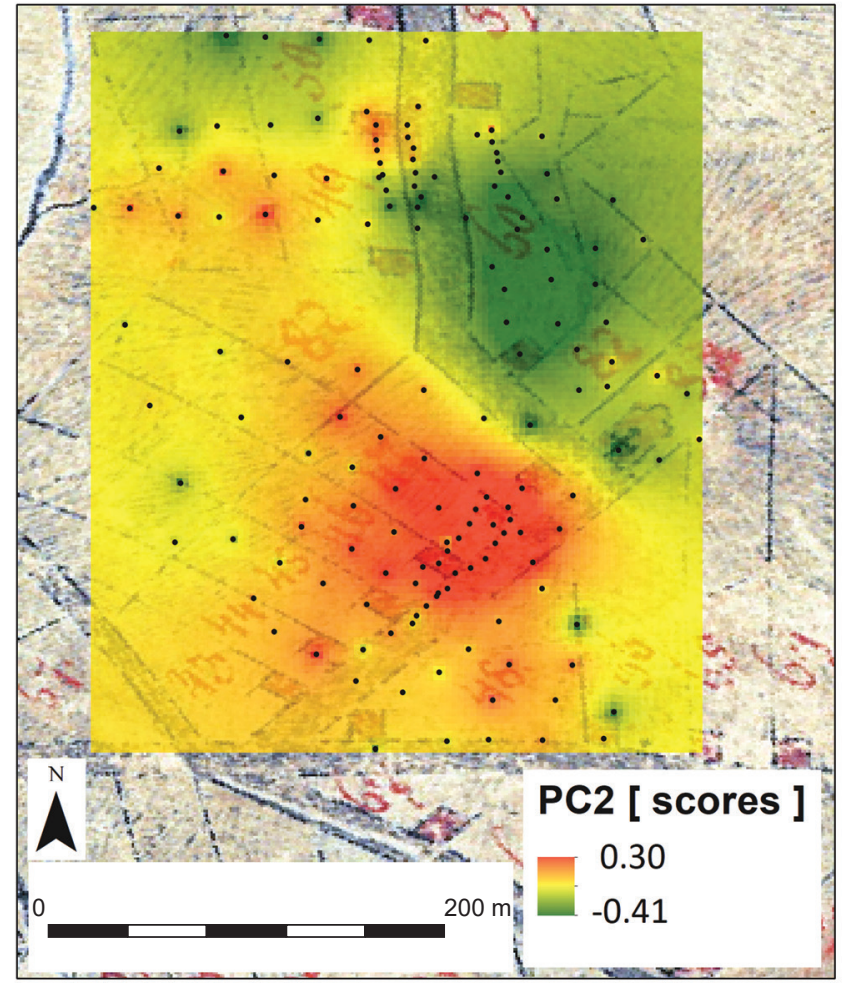

Figure 12. Interpolated scores of $\mathrm{PC} 2$ in the sampled area.

According to the spatial distribution of elemental content, we could say that there was no element whose content (and its gradient) would clearly distinguish the area of mapped 


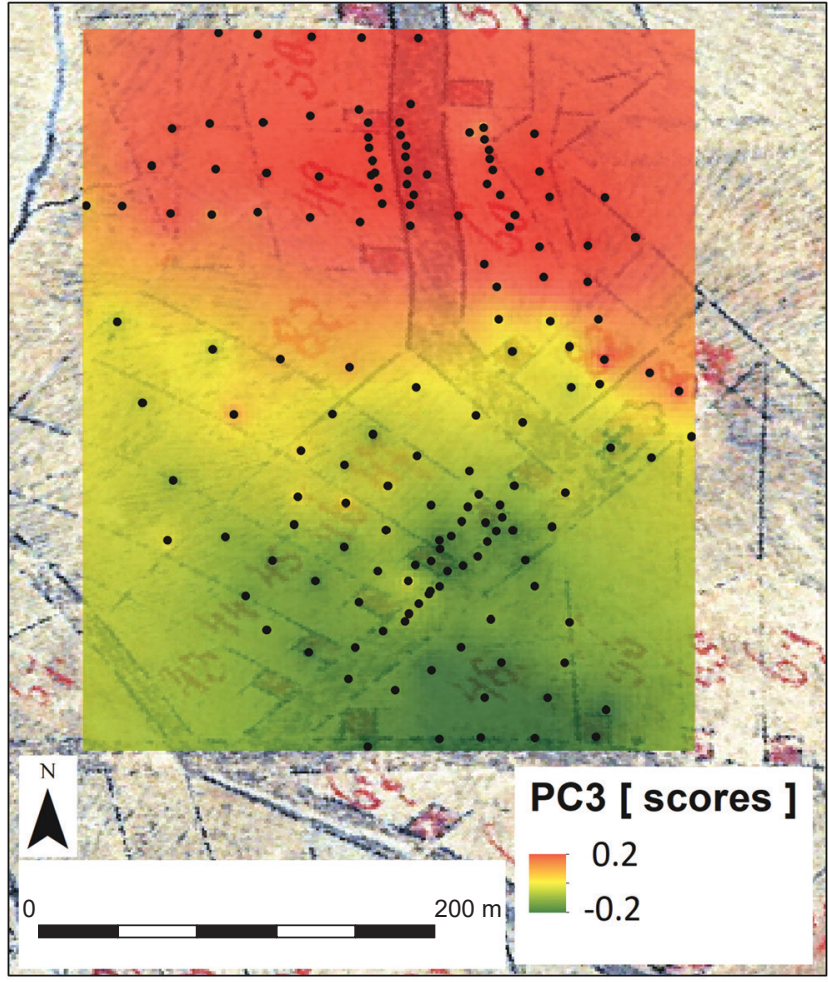

Figure 13. Interpolated scores of $\mathrm{PC} 3$ in the sampled area.

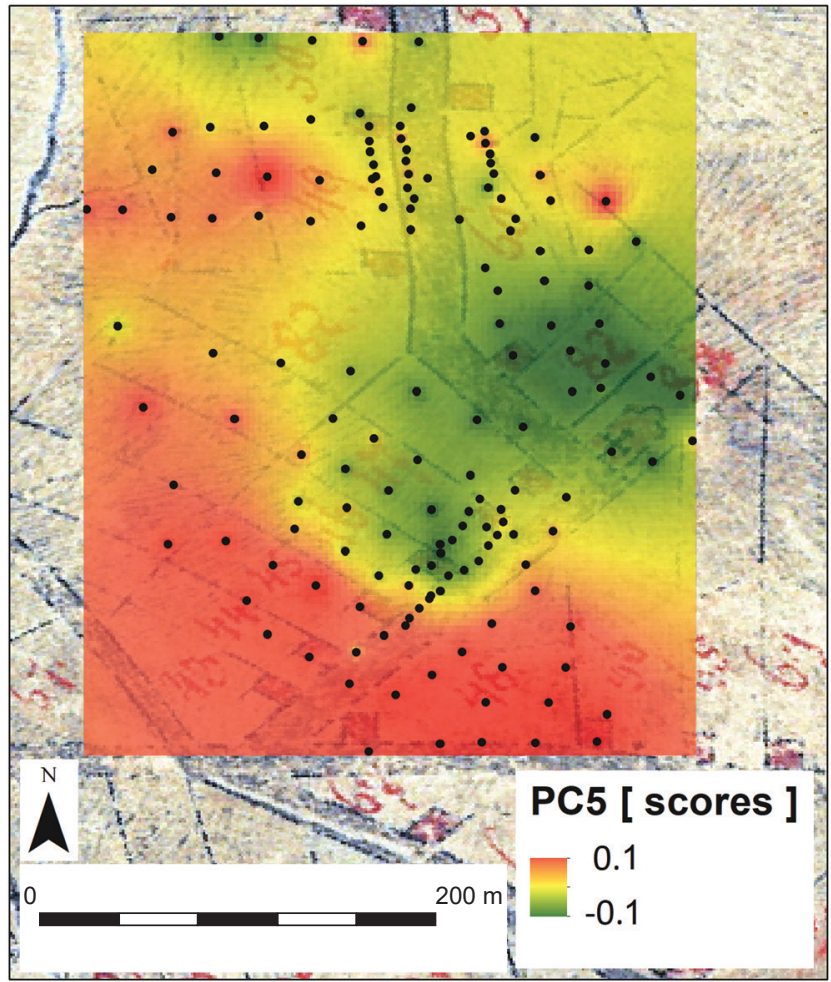

Figure 15. Interpolated scores of PC5 in the sampled area.

households against the surrounding areas. We have found two patterns according to the planned built-up area. The first pattern was based on a distinct gradient in a north-south

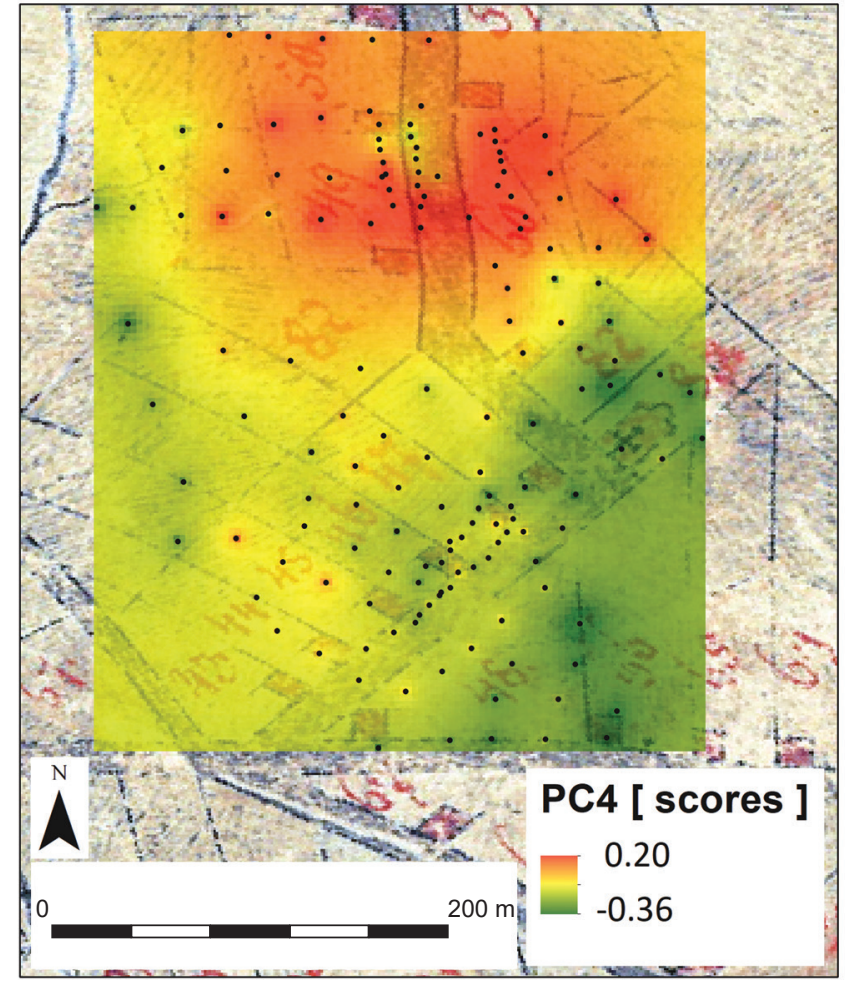

Figure 14. Interpolated scores of PC4 in the sampled area.

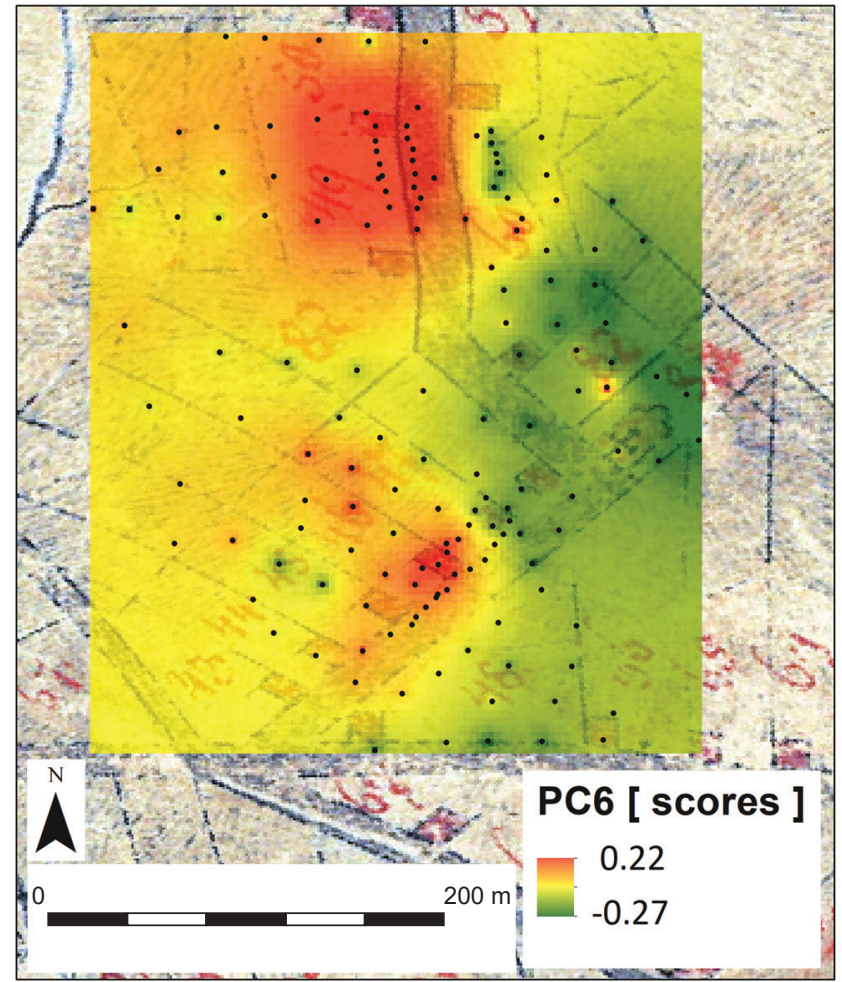

Figure 16. Interpolated scores of PC6 in the sampled area.

direction and loosely copied the elevation of the terrain. Such elements were $\mathrm{Si}, \mathrm{S}, \mathrm{Ca}, \mathrm{Mn}$ and $\mathrm{Pb}$ (see Figures 5, 6 and 9). The other, second, pattern was not easy to describe, but 
according to the planned households, we could say that the second pattern was at least somehow manifested in more parts of the households in the lower and higher elevations. As examples, we could state $\mathrm{P}, \mathrm{K}, \mathrm{Fe}, \mathrm{Zn}, \mathrm{Rb}$ or $\mathrm{Zr}$ for this pattern (see Figures 7, 8 and 10).

The PCA extracted 15 components, but we further present and discuss only PC1 to PC6 as the other components only explained a very low proportion of variability. For information concerning the PCA, see Table 2. The first component PC1 explained over $35 \%$ of variability. It was positively linked to $\mathrm{P}$ and $\mathrm{S}$ and to a lesser extent to $\mathrm{K}$, $\mathrm{Ca}, \mathrm{Zn}$, Th and LE. It was negatively linked to $\mathrm{Fe}, \mathrm{Rb}, \mathrm{Sr}$ and Zr. The second component PC2 explained over $15 \%$ of variability and was positively linked to elevation, $\mathrm{K}$ and $\mathrm{Sr}$ and negatively to Si. The third component PC3 explained over $10 \%$ of variability and was positively linked to Ca and negatively to Si. PC4 explained almost $9 \%$ of variability and was strongly linked to Mn (positively). PC5 explained almost $7 \%$ of variability and was linked mainly to $\mathrm{Zn}$ (negatively). PC6 explained almost 6\% of variability and was linked mainly to $\mathrm{Pb}$ (negatively).

Spatial characteristics of the PCs 1-6 can be described as they recorded similar patterns to those of the contents of elements: PC1 and PC3 followed the pattern of a distinct north-south gradient, and PCs 2, 4, 5, 6 recorded that somewhat unclear pattern in which both main parts of the planned households reached similar values (for examples, see Figures 11-16).

\section{Discussion}

\subsection{Elemental content and PCA results}

Geochemical research in areas of previous human activities has been performed many times in the past. We might mention the searching of sites using the "almost undeniable" human indicator phosphorus (e.g. Zöllitz, 1983, generally Holliday and Gartner, 2007), using analyses of the content of many elements (Entwistle et al., 1998; 2000; Wilson et al., 2005; 2008; 2009), or also using multivariate analyses on the same (Salisbury, 2013). Such methods usually work regardless of the measurement method or method of extraction. Previous studies have used, for example, the ICP method, but this generally works with other methods like PXRF (Horák and Klír, 2017; Horák et al., 2018; Janovský and Horák, 2018; Janovský et al., 2019; Šmejda et al., 2017; 2018). Although PXRF gives the total content of the elements, studies using ICP usually work with just the fraction after digestion, which does not give total content. Nevertheless, we see the results as being comparable between studies: not by absolute values, but by the complex of elements which are usually interpreted as human activity indicators (see citations above). Such "indicator" elements are usually always the same. Also, for example, Wilson et al. (2005) used nitric acid for their extraction method, which gives pseudo-totals, but obtained similar results.

Such studies are methodologically based on two principles: i) searching the unknown location of a site

Table 2. PCA results: loadings of variables for PC1 to PC6.

\begin{tabular}{|c|c|c|c|c|c|c|}
\hline & PC1 & PC2 & PC3 & PC4 & PC5 & PC6 \\
\hline elevation & 0.43 & 0.59 & -0.1 & 0.36 & 0.11 & -0.38 \\
\hline $\mathrm{Si}$ & -0.24 & -0.56 & -0.52 & 0.18 & 0.41 & 0.02 \\
\hline $\mathrm{P}$ & 0.75 & 0.03 & 0.36 & -0.14 & 0.36 & -0.06 \\
\hline $\mathrm{S}$ & 0.79 & -0.21 & 0.20 & -0.10 & 0.29 & -0.08 \\
\hline K & 0.42 & 0.52 & -0.34 & -0.26 & 0.11 & 0.27 \\
\hline $\mathrm{Ca}$ & 0.50 & 0.18 & 0.69 & 0.03 & -0.12 & -0.12 \\
\hline $\mathrm{Mn}$ & 0.17 & 0.18 & -0.21 & 0.88 & -0.07 & 0.13 \\
\hline $\mathrm{Fe}$ & -0.76 & -0.47 & 0.27 & -0.08 & -0.03 & 0.14 \\
\hline $\mathrm{Zn}$ & 0.50 & -0.37 & 0.23 & 0.32 & -0.52 & 0.24 \\
\hline $\mathrm{Rb}$ & -0.86 & 0.35 & 0.10 & -0.06 & -0.05 & 0.01 \\
\hline $\mathrm{Sr}$ & -0.56 & 0.69 & 0.19 & -0.03 & -0.08 & 0.00 \\
\hline $\mathrm{Zr}$ & -0.78 & 0.46 & -0.06 & -0.05 & 0.01 & 0.07 \\
\hline $\mathrm{Pb}$ & -0.48 & -0.33 & -0.11 & -0.02 & -0.23 & -0.69 \\
\hline $\mathrm{Th}$ & 0.67 & 0.21 & -0.42 & -0.17 & -0.20 & -0.14 \\
\hline LE & 0.52 & -0.04 & -0.40 & -0.40 & -0.45 & 0.04 \\
\hline eigenvalue & 5.33 & 2.36 & 1.61 & 1.35 & 0.99 & 0.85 \\
\hline$\%$ variability & 35.52 & 15.72 & 10.7 & 8.97 & 6.62 & 5.66 \\
\hline cumulative $\%$ & 35.52 & 51.25 & 61.95 & 70.92 & 77.54 & 83.19 \\
\hline
\end{tabular}


based on those "almost undeniable" indicators such as $\mathrm{P}$, or on the interaction of more of such elements (and, of course, sometimes it does not work); ii) the analyses are performed in an area of known historical/prehistorical activity, or more of such activities, enabling some patterns in elemental composition to be distinguished, based on those known activities.

As the situation of Eibenthal was based on the plan, with its unknown state of realization, and thus with an unknown state and distribution of potential human activities, the research was a variant of the first principle. In such a case as this, clear interpretation would need clear and well distinguished patterns of human indicator elements, or principal components connected to them. As such potential indicators, we could see these elements in our dataset: $\mathrm{P}, \mathrm{K}$, $\mathrm{Ca}, \mathrm{Mn}, \mathrm{Zn}, \mathrm{Sr}$ and Th, based on cited studies. By a "welldistinguished" pattern, we mainly mean the general gradient of high content in the area of houses and their close vicinity (courtyards, gardens), with lower values in the area of, presumably, manured fields and the lowest values in the open landscape.

We did not find any such pattern which would be recorded in the area of all households, but we did find some patterns loosely similar in their distribution connected to some parts of the households (the northernmost part or the northern part, plus a few households from the southern part). As we did not know which parts were actually inhabited (even if there were any at all), the following interpretations are presented in two variants and are strongly speculative. Only the "human indicator" elements and the principal components (PCs) connected to them are discussed.

The pattern of high values manifested mainly in the northern part of the area was found in the case of the element $\mathrm{Ca}$, and in PC1 and PC3. The pattern connecting the northern and southern parts of the area was found to be recorded by the elements P and K, and PC4 and PC6. Therefore, we could speculate that, according to such results, potential human activity and the inhabitation of households were connected either to the northern part only, or to both the northern and southern parts. No distinguished human indicator or PC was clearly connected to the central part of the area around the church/chapel. We can definitely reject the possibility of all households having been inhabited intensively for any considerable length of time. Such a situation would probably leave more clear patterns than was found (for a comparison, see $\mathrm{H}, \mathrm{J})$.

We have two main problems to deal with in both interpretations: they are strongly speculative, as we do not have any independent mean of testing the results; and the material is imprecise (we do not know the realized state of the planning and weather is it methodical). And the spatial distribution of potential human indicators was following the aforementioned pattern only very loosely: there were high values not only in the area of households, but also farther away in the fields. We could expect at least some gradient, even if the fields were manured. This problem was not just an artefact coming from the interpolation's setting (we tested more variants with similar results). To get better and clearer results in potential future research of this or similar sites, it would be helpful to use more methods. For the geochemical data, it would be good to use some other methods and extractions to obtain not only the total content of elements, and to use a more focused sampling design with a denser grid. To find possible underground features, geophysical methods should be used. The field application of such methods, or the planning of a sampling design, should also be based on the results of previous archaeological-topographical surveys. We could say that in cases of an unclear historical context (where knowledge of which households were inhabited is imprecise); the geochemical mapping needs to be supported by the use of further different methods and denser sampling grids.

\subsection{Eibenthal households}

Geochemical mapping is able to reveal spatial patterns that may be interpreted as the results of past human activities, settlement or agriculture. We could not interpret these patterns clearly mainly due to the lack of context (geological, soil, historical). We did not find any PC or element that could be clearly connected to Eibenthal activities. However, based on a comparison of the PCs or elements that could be interpreted in this way (with only some probability); it seemed that there was no united pattern. These PCs indicated that there was no unity in the sampled area from the village settlement point of view. There was either a high diversity in household management (technical or agricultural), or some of the households did not exist or existed only for a limited period of time. Because the first option was not probable from a historic point of view (the purpose of settlement, the ways of realizing it), and the second option was more probable (hard beginnings of colonization, attempts to abandon the sites and movement to more suitable localities), we see the second option as being more suitable to the above-mentioned (yet still speculative) interpretation of Eibenthal. However, it was not unusual that the original plans differed from the later realized situation; similar complications with village foundations have also been observed in medieval central Europe (Klápště, 2012).

The popular oral history revealed in the grey literature also supports the above hypothesis. According to the popular history, Eibenthal village was removed to the present position several years after its foundation. The previous position of the village should be on the northern slope and plateau, but the precise localization varies according to different authors (Gecse, 2013; Urban, 2005). This would be in accordance with the geochemical mapping, which definitely did not find records of intensive inhabitation over the whole area. According to the local oral history, the reason for the transfer was the water shortage that occurred after deforestation. Meanwhile, the old military maps of the Second and Third Military Surveys depict the real position of the village in the second half of the nineteenth century. The map from 1826 is a unique document of a planned colonization that was never realized to the extent envisaged. 


\section{Conclusion}

The first aim of the paper was to determine if Eibenthal's settlement was carried out to the extent that was recorded on old maps. It was proved that the oldest map from 1826 depicts the planned rather than the actual extent of the settlement, which means that the map from 1826 is a very important and rare document. Some authors (Gecse, 2013; Jech et al., 1992; Secká, 1995; Urban, 2005) indicate that the military officer prepared the plans for the households and fields before the Banat villages were settled in the $1820 \mathrm{~s}$, but none of these plans were published. This plan of the prepared settlement was found by chance in the cadastral office in Orşova when we asked for the stable cadastral maps. This unique document was compared with other old maps, and the spatial development of the rural settlement in Romanian Banat was then analysed.

The geochemical mapping revealed possible human activities connected with settlement and agriculture in this area, but not with a pattern that could be well interpreted - and we would recommend the use of other different methods in similar contexts as the case here. Nevertheless, the results seemed to be in accordance with the popular history (Gecse, 2013; Urban, 2005), according to which some settlement activities were carried out in this location but were abandoned.

\section{Acknowledgments}

This work was supported by the Internal Grant Agency of the Faculty of Environmental Sciences, CULS Prague, Grant No. 4219013123139 "Vliv geografických faktorů na vybrané procesy v dějinách osídlení - The influence of geographical factors on selected processes in settlement history" and by Institutional support from the Silva Tarouca Research Institute for Landscape and Ornamental Gardening, No. VUKOZ-IP-00027073.

\section{Data availability}

The original geochemical data are available in Dataset S1 (see Supplementary Online Material).

\section{References}

ANTROP, M., 2005. Why landscapes of the past are important for the future. Landscape and Urban Planning, 70, 21-34.

BISZAK, E., KULOVITS, H., BISZAK, S., TIMÁR, G., MOLNÁR, G., SZÉKELY, B., JANKÓ, A., and KENYERES, I., 2014. Cartographic heritage of the Habsburg Empire on the web: the MAPIRE initiative. In: G. Gartner, ed. $9^{\text {th }}$ International Workshop on Digital Approaches to Cartographic Heritage. Budapest: ICA Commission on Digital Technologies in Cartographic Heritage - Eötvös Loránd University National Széchényi Library, pp. 26-31.

BORK, H.R., BORK, H., DALCHOW, C., FAUST, B., PIORR, H.P., and SCHATZ, T., 1998. Landschaftsentwicklung in Mitteleuropa. Gotha-
Stuttgart: Klett-Perthes Verlag.

CANTI, M., HUISMAN, D.J., 2015. Scientific advances in geoarchaeology during last twenty years. Journal of Archaeological Science, 56, 96-108.

CEPRAGA, T., 2014. The Dynamics of Clopotiva Village. A Cartographical Analysis. Cinq Continents, 4(9), 61-73.

CZOERNIG, K. von, 1857. Ethnographie der Oesterreichischen Monarchie III. Wien: Kaiserlich- Koeniglichen Hof- und Staatsdruckerei.

DAVIDSON, D.A., WILSON, C.A., MEHARG, A.A., DEACON, C., and EDWARDS, K.J., 2007. The legacy of past manuring practices on soil contamination in remote rural areas. Environment International, 33, 78-83.

DOSSCHE, R., ROGGE, E., and VAN EETEVELDE, V., 2016. Detecting people's and landscape's identity in a changing mountain landscape. An example from the northern Apennines. Landscape Research, 41(8), 934-949.

ENTWISTLE, J.A., ABRAHAMS, P.W., and DODGSHON, R.A., 1998. Multi-Element Analysis of Soils from Scottish Historical Sites. Interpreting Land-Use History Through the Physical and Geochemical Analysis of Soil. Journal of Archaeological Science, 25, 53-68.

ENTWISTLE, J.A., ABRAHAMS, P.W., and DODGSHON, R.A., 2000. The Geoarchaeological Significance and Spatial Variability of a Range of Physical and Chemical Soil Properties from a Former Habitation Site, Isle of Skye. Journal of Archaeological Science, 27, 287-303.

FANTA, V., ŠÁLEK, M., ZOUHAR, J., SKLENIČKA, P., and STORCH, D. 2018. Equilibrium dynamics of European pre-industrial populations: the evidence of carrying capacity in human agricultural societies, Proceedings of the Royal Society B: Biological Sciences, 285(1871).

FOREJT, M., SKALOŠ, J., PEREPONOVÁ, A., PLIENINGER, T., VOJTA, J., and ŠANTRŮČKOVÁ, M., 2017. Changes and continuity of wood-pastures in the lowland landscape in Czechia. Applied Geography, 79, 235-244.

GECSE, D., 2013. Historie českých komunit v Rumunsku. Praha: Herrmann \& synové.

HEJCMAN, M., KARLÍK, P., ONDRÁČEK, J., and KLÍR, T., 2013. ShortTerm Medieval Settlement Activities Irreversibly Changed Forest Soils and Vegetation in Central Europe. Ecosystems, 16(4), 652-663.

HEJCMAN, M., SOUČKOVÁ, K., and GOJDA, M., 2013. Prehistoric settlement activities changed soil $\mathrm{pH}$, nutrient availability, and growth of contemporary crops in Central Europe. Plant and Soil, 369(1-2), $131-140$.

HEROLDOVÁ, I., 1986. Reemigrace zahraničních Čechů a Slováků po 2. světové válce. In: S. Brouček, ed. Češi v cizině 1. Praha: Ústav pro etnografii a folkloristiku ČSAV - Československý ústav zahraniční v Praze, pp. 153-164.

HILL, L., 2013. Archaeologies and geographies of the post-industrial past: landscape, memory and the spectral. Cultural Geographies, 20(3), 379396.

HOLLIDAY, V.T., and GARTNER, W.G., 2007. Methods of soil P analysis in archaeology. Journal of Archaeological Science, 34, 301-333.

HORÁK, J., KLÍR, T., 2017. Pedogenesis, pedochemistry and the functional structure of the Waldhufendorf field system of the deserted medieval village Spindelbach, the Czech Republic. Interdisciplinaria Archaeologica - Natural Sciences in Archaeology, 8(1), 43-57.

HORÁK, J., JANOVSKÝ, M., HEJCMAN, M., ŠMEJDA, L., KLÍR, T., 2018. Soil geochemistry of medieval arable fields in Lovětín near Třešt', Czech Republic. Catena, 162, 14-22.

IORDACHE, C., 2007. Gârnic. The specifity of a Czech community in Romania. Analele Universitarii din Craiova. Serie Geografica, 10, 206216.

JANOVSKÝ, M., HORÁK, J., 2018. Large Scale Geochemical Signatures Enable to Determine Landscape Use in the Deserted Medieval Villages. Interdisciplinaria Archaeologica - Natural Sciences in Archaeology, 9(1), 71-80.

JANOVSKÝ, M., KARLÍK, P., HORÁK, J., ŠMEJDA, L., OPARE, M.A., BENEŠ, J., HEJCMAN, M., 2020. Historical land-use in an abandoned mountain village in the Czech Republic is reflected by the $\mathrm{Mg}, \mathrm{P}, \mathrm{K}, \mathrm{Ca}$, $\mathrm{V}, \mathrm{Cr}, \mathrm{Mn}, \mathrm{Fe}, \mathrm{Ni}, \mathrm{Cu}, \mathrm{Zn}, \mathrm{Rb}, \mathrm{Zr}$, and $\mathrm{Sr}$ content in contemporary soils. Catena, online version: https://doi.org/10.1016/j.catena.2019.104347

JECH, J., SECKÁ, M., SCHEUFLER, V., and SKALNÍKOVÁ, O., 1992. České vesnice v rumunském Banátě. Praha: Ústav pro etnografii a folkloristiku ČSAV. 
JEPSEN, M.R. et al., 2015. Transitions in European land-managemen regimes between 1800 and 2010. Land Use Policy, 49, 53-64.

KLÁPŠTĚ, J., 2012. The Czech Lands in Medieval Transformation. Boston: Brill Leiden.

KOVÁř, P., ed., 2019. Přenesená krajina. Český venkov v rumunském Banátu. Praha: Academia.

KRISTIANSEN, S.M., 2001. Present-day soil distribution explained by prehistoric land-use: Podzol - Arenosol variation in an ancient woodland in Denmark. Geoderma, 103, 273-289.

KUEMMERLE, T., LEVERS, C., ERB, K., ESTEL, S., JEPSEN, M.R., MÜLlER, D., PLUTZAR, C., STÜRCK, J., VERKERK, P.J., VERBURG, P.H., and REENBERG, A., 2016. Hotspots of land use change in Europe. Environmental Research Letters, 11(6), 1-14.

LIMPERT, E., STAHEL, W.A., and ABBT, M., 2001. Log-normal Distributions across the Sciences: Keys and Clues. Bioscience, 51, 341352.

NIELSEN, N.H., and KRISTIANSEN, S.M., 2014. Identifying ancient manuring: traditional phosphate vs. multi-element analysis of archaeological soil. Journal of Archaeological Science, 42, 390-398.

PAVLÁSEK, M., 2010. Exkurs do historie Banátské vojenské hranice $\mathrm{s}$ přihlédnutím k vzniku českých enkláv na jejím území. Slovansky prehled. Review for the History of Central, Eastern and Southeastern Europe, 96(3-4), 243-262.

PÎRNĂU, R.G., PATRICHE, C.V., ROŞCA, B., VASILINIUC, I., VORNICU, N., STANC, S., 2020. Soil spatial patterns analysis at the ancient city of Ibida (Dobrogea, SE Romania), via portable X-ray fluorescence spectrometry and multivariate statistical methods. Catena, $189,1-12$.

REIMANN, C., and FILZMOSER, P., 2000. Normal and lognormal data distribution in geochemistry: death of a myth: Consequences for statistical treatment of geochemical and environmental data. Environmental Geology, 39, 1001-1014.

REIMANN, C., FILZMOSER, P., FABIAN, K., HRON, K., BIRKE, M., DEMETRIADES, A., DINELLI, E., and LADENBERGER, A., 2012. The concept of compositional data analysis in practice: Total major element concentrations in agricultural and grazing land soils of Europe. Science of the Total Environment, 426, 196-210.

REIMANN, C., FILZMOSER, P., GARRETT, R., and DUTTER, R., 2008. Statistical Data Analysis Explained. Applied Environmental Statistics with $R$. Chichester: John Wiley \& Sons Ltd.

ROMPORTL, D., HAVLÍČEK, M., CHUMAN, T., SKOKANOVÁ, H., and ŠANTRŮČKOVÁ, M., 2014. The development of land use and landscape structure. In: P. Maděra, ed. Czech villages in Romanian Banat: Landscape, nature, and culture. Brno: Mendel University, pp. 277-291.

ROOS, C.I., and NOLAN, K.C., 2012. Phosphates, Plowzones, and Plazas: a Minimally Invasive Approach to Settlement Structure of Plowed Village Sites. Journal of Archaeological Science, 39, 23-32.

SALISBURY, R.B., 2013. Interpolating geochemical patterning of activity zones at Late Neolithic and Early Copper Age settlements in eastern Hungary. Journal of Archaeological Science, 40, 926-934.

SALISBURY, R.B., 2016. Soilscapes in Archaeology: Settlement and Social Organization in the Neolithic of the Great Hungarian Plain. Budapest: Archaeolingua.

ŠANTRŮČKOVÁ, M., DOSTÁLEK, J., and DEMKOVÁ, K., 2015. Assessing long-term spatial changes of natural habitats using old maps and archival sources: a case study from Central Europe. Biodiversity and Conservation, 24(8), 1899-1916.

ŠANTRƯČKOVÁ, M., and FANTA, V., 2014. Př́íspěvek k lokalizaci zaniklé české vesnice Elizabeta v rumunském Banátu. Český lid, 101(3), 279-298.
ŠANTRU゚ČKOVÁ, M., and KLVAČ, P., 2014. The history and present of Czech settlements in the Romanian Banat. In: P. Maděra, ed. Czech villages in Romanian Banat: Landscape, nature, and culture. Brno: Mendel University, pp. 33-48.

SCHREG, R., 2014. Ecological Approaches in Medieval Rural Archaeology. European Journal of Archaeology, 17(1), 83-119.

SECKÁ, M., 1995. Češi v rumunském Banátu. In: S. Brouček, ed. Češi $v$ cizině 8. Praha: Ústav pro etnografii a folkloristiku AV ČR v Praze, pp. 92-115.

SKALOŠ, J., WEBER, M., LIPSKÝ, Z., TRPÁKOVÁ, I., ŠANTRŮČKOVÁ, M., UHLÍŘOVÁ, L., and KUKLA, P., 2011. Using old military survey maps and orthophotograph maps to analyse long-term land cover changes - Case study (Czech Republic). Applied Geography, 31(2), 426-438.

SOLYMOSI, K., 2011. Indicators for the Identification of Cultural Landscape Hotspots in Europe. Landscape Research, 36(1), 3-18.

SOUČKOVÁ, K., HEJCMAN, M., and KLÍR, T., 2013. Medieval Farming Practices in Deserted Villages Can be Determined Based on the Nitrogen Isotopic Signature in Recent Forest Soils. Interdisciplinaria Archaeologica, Natural Sciences in Archaeology, 4(1), 63-71.

ŠMEJDA, L., HEJCMAN, M., HORÁK, J., SHAI, I., 2017. Ancient settlement activities as important sources of nutrients $(\mathrm{P}, \mathrm{K}, \mathrm{S}, \mathrm{Zn}$ and $\mathrm{Cu})$ in Eastern Mediterranean ecosystems - The case of biblical Tel Burna, Israel. Catena, 156, 63-72.

ŠMEJDA, L., HEJCMAN, M., HORÁK, J., SHAI, I., 2018. Multi-element mapping of anthropogenically modified soils and sediments at the Bronze to Iron Ages site of Tel Burna in the Southern Levant. Quaternary International, 483, 111-123.

ŠTĚPÁNEK, V., 2005. Česká kolonizace Banátské vojenské hranice na území srbsko-banátského hraničářského pluku. In: L. Hladký, ed. Od Moravy k Moravě: Z historie česko-srbských vztahů v 19. a 20. století. Brno: Matice moravská, pp. 72-101.

URBAN, R., 2005. Češi a Slováci v Rumunsku. Nadlak: Ivan Krasko.

VACULÍK, J., 1993. Reemigrace zahraničnich Čechủ a Slováků v letech 1945-1950. Brno: Masarykova univerzita.

WALKINGTON, H., 2010. Soil science applications in archaeological context: A review of key challenges. Earth-Science Reviews, 103, 122134.

WILSON, C.A., DAVIDSON, D.A., and CRESSER, M.S., 2005. An evaluation of multielement analysis of historic soil contamination to differentiate space use and former function in and around abandoned farms. The Holocene, 15, 1094-1099.

WILSON, C.A., DAVIDSON, D.A., and CRESSER, M.S., 2008. Multielement soil analysis: an assessment of its potential as an aid to archaeological interpretation. Journal of Archaeological Science, 35, $412-424$

WILSON, C.A., DAVIDSON, D.A., and CRESSER, M.S., 2009. An evaluation of the site specificity of soil elemental signatures for identifying and interpreting former functional areas. Journal of Archaeological Science, 36, 2327-2334.

WULF, M., JAHN, U., and MEIER, K., 2016. Land cover composition determinants in the Uckermark (NE Germany) over a 220-year period. Regional Environmental Change, 16(6), 1793-1805.

ZÖLLITZ, L., 1983. Bodenchemische Untersuchungen im Bereich vor- und frühgeschichtlicher Siedlungen. Schriften des Naturwissenschaftlichen Vereins für Schleswig-Holstein, 53, 33-57.

\section{Web page:}

http://mapire.eu/en/ 
